\title{
Przekształcenia powierzchni brzegów rzecznych przez procesy mrozowe
}

\author{
Transformations of the surface of riverbanks by frost processes
}

\author{
Karol Augustowski, Józef Kukulak \\ Instytut Geografii,Uniwersytet Pedagogicznyim.KEN, Kraków,kaugustowski@wp.pl
}

Zarys treści: Zbadano skutki procesów mrozowych na podciętych brzegach rzek w okresie listopad-kwiecień przełomu lat 2011/2012 r. Erozję powierzchni brzegów w dorzeczu Czarnego Dunajca (Kotlina Orawska, Pogórze Gubałowskie) oraz w dorzeczu Ropy (Beskid Niski) badano metodą prętów pomiarowych i łapaczami materiału osypiskowego. Procesy mrozowe były tam aktywne w 4-5 okresach multigelacji. Wykazano, że spowodowały największą erozję powierzchni brzegów skalistych, mniejsza była erozja brzegów zbudowanych ze żwirów średnich i grubych, a najmniejsza brzegów zbudowanych z piasków i glin. Na rozmiary tej erozji miała wpływ nie tylko litologia utworów i stopień ich spoistości, ale także obecność i gęstość spękań.

Słowa kluczowe: procesy mrozowe, erozja, brzegi rzek, Podhale, Beskid Niski

\begin{abstract}
The effects of frost processes on undercut riverbanks in the period November-April, at the turn of 2011/2012 were examined. Erosion of the riverbanks in the Czarny Dunajec basin (Orava Basin, Gubałówka Hills) and in the Ropa basin (Low Beskid) was studied by erosion pins and catchers of bank sediments. There were 4-5 multigelation periods. It has been shown that the frost processes caused the largest erosion in area of rocky banks; erosion was smaller on banks built with medium and coarse gravels, and the smallest on banks built with sands and clays. The size of this erosion was influenced not only by lithology and the degree of cohesion, but also the presence and density of cracks.
\end{abstract}

Key words: frost processes, erosion, riverbanks, Podhale, Low Beskid

\section{Wstęp}

Cofanie się brzegów rzecznych jest wynikiem aktywności wielu procesów. Do najważniejszych należą: działalność wód płynących i opadowych, ruchy masowe oraz procesy subaeralne (Zwoliński 1988). Wśród tych ostatnich dominującą rolę odgrywają procesy mrozowe, które w przeciwieństwie do poglądów m.in. Wolmana (1959), Thorne'a (1990) czy Coupera (2003) bezpośrednio wpływają na przekształcenia powierzchni brzegu. Natężenie i skutki działania tych procesów mogą być różne, ponieważ decyduje o nich wiele warunków natury klimatycznej i samego środowiska brzegów. Ich przebieg zależny jest od: uziarnienia gruntu (np. Wolman 1959, Walker i in. 1987) i jego wilgotności (np. Thorne, Osman 1988) oraz stanu fizycz- nego tej wilgoci (Thorne 1990), porowatości i gęstości gruntu oraz zawartości w nim materii organicznej (Grissinger 1982, Knapen i in. 2007), kąta nachylenia brzegu (np. Allen i in. 1999, Wynn 2004, Kozielska-Sroka i in. 2010), liczby cykli zamarzania/odmarzania (Miller 1980), stopnia spójności materiału budującego brzegi (Mitchell i in. 2003), głębokości przemarzania gruntu (Webb i in. 1983), obecności pokrywy roślinnej (np. Thorne 1982, Przedwojski 1998, Hubble i in. 2010) lub śnieżnej (np. Gatto 1995, Dolnicki 2002). Dotychczasowe badania tego zagadnienia skupiały się głównie na brzegach homogenicznych, zbudowanych $\mathrm{z}$ drobnych aluwiów. Wyniki swoich pomiarów na takich brzegach przedstawili m.in.: Reid (1985), który stwierdził 20-80\% udziału erozji mrozowej w całkowitej erozji brzegu (na przykładzie jeziora 
Orwell), Lawler (1993) - udział procesów mrozowych oceniał na 32-43\%, czy Teisseyre (1984), który uznał multigelację za jeden z głównych czynników wpływających na tempo cofania się brzegów rzecznych. Nie wykonano dotąd badań podatności na procesy mrozowe brzegów skalistych i zbudowanych $\mathrm{z}$ aluwiów różnoziarnistych, w warunkach jednorodnych klimatycznie. Niniejsze opracowanie jest próbą oceny skutków morfologicznych działania procesów zamarzania/odmarzania (multigelacji) na brzegach o różnej budowie geologicznej.

\section{Przestrzenny i czasowy zakres badań}

W celu ustalenia wielkości erozji mrozowej na brzegach skalistych i aluwialnych wybrano do analizy dwa odcinki brzegów piaszczysto-gliniastych (Korczyna, Sękowa), cztery brzegi zbudowane ze średnich i grubych żwirów (Bielanka 1, Bielanka 2, Chochołów, Gładyszów) oraz dwa brzegi skaliste z fliszu (Rozdziele, Ciche). Badane brzegi znajdują się w dorzeczu Ropy (Beskid Niski) (ryc. 1A) i na podhalańskim odcinku dorzecza Czarnego Dunajca (Chochołów, Ciche) (ryc. 1B). Badania prowadzono w okresie listopad-kwiecień na przełomie 2011 i 2012 r. Do określenia wielkości erozji brzegu w miejscach badanych wykorzystano pręty pomiarowe (ang. erosion pins) (ryc. 2A), używane powszechnie w badaniach erozji (np. Zwoliński 1988, Lawler 1993, Saynor i in. 1994, Couper, Maddock 2001, Hupp i in. 2009). Do zmierzenia kubatury materiału osypiskowego na stanowiskach badawczych użyto drewnianych łapaczy (ryc. 2B).

Pomiary na brzegach wykonywano w kolejnych okresach multigelacji (okresach, w których notowano wielokrotne przypowierzchniowe wahania temperatury powietrza wokół $0^{\circ} \mathrm{C}$ ). W okolicach Beskidu Niskiego wystąpiły 4 takie okresy (pierwsza dekada stycznia, druga dekada lutego, pierwsza dekada marca oraz przełom marca i kwietnia), na Podhalu - pięć okresów (pierwsza dekada stycznia, druga dekada lutego, pierwsza dekada marca, przełom marca i kwietnia oraz druga dekada kwietnia). Dla wykluczenia powiązań działania procesów mrozowych $\mathrm{z}$ erozją fluwialną prowadzono rejestrację wodostanów Czarnego Dunajca i Ropy na trzech stacjach pomiarowych IMGW: Koniówka, Ropa i Klęczany (ryc. 3 ). W całym okresie badawczym poziom wody w rzekach oscylował w przedziale stanów niskich i średnich.

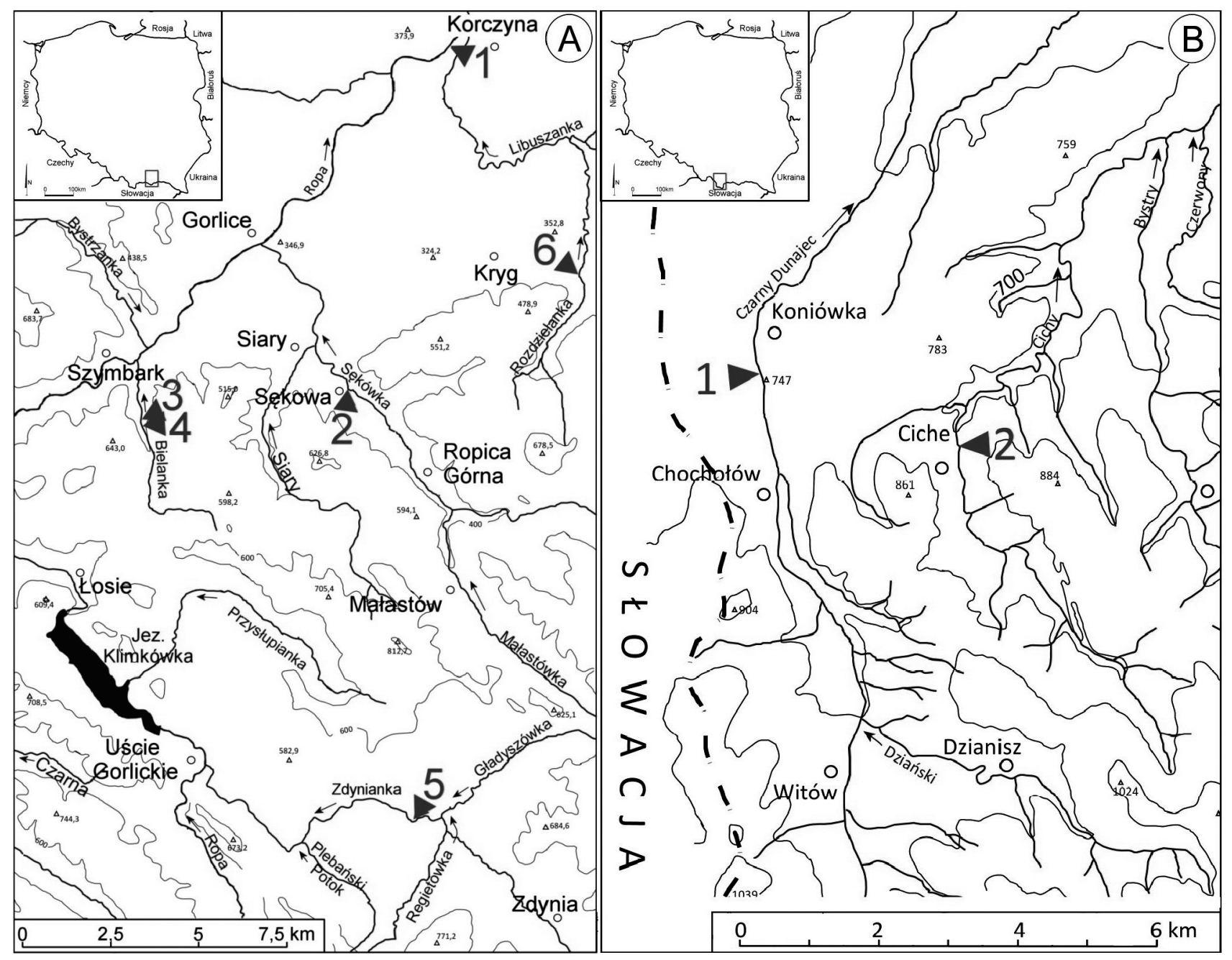

Ryc. 1. Lokalizacja stanowisk badawczych

Fig. 1. Study sites location 

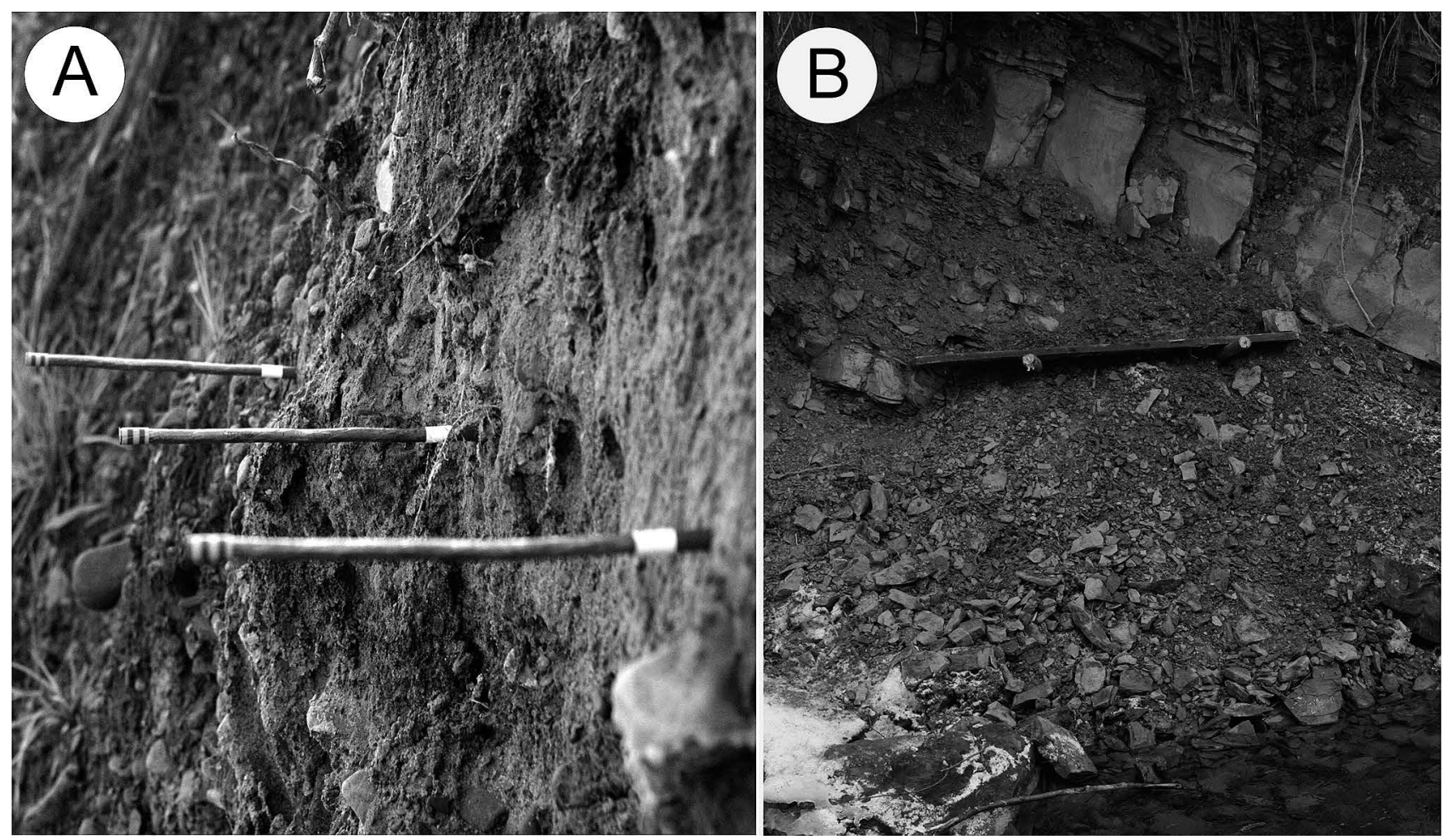

Ryc. 2. Pręty pomiarowe (A) oraz łapacze materiału osypiskowego (B)

Fig. 2. Erosion pins (A) and bank sediment catchers (B)

\section{Opis stanowisk badawczych}

\section{Brzegi zbudowane z piasków i glin}

1. Korczyna (nr 1 na ryc. $1 \mathrm{~A}$ ) - stanowisko pomiarowe na prawym brzegu Ropy. Jest podcięciem erozyjnym terasy o wysokości $2,5 \mathrm{~m}$. Stok tego brzegu ma w tym miejscu nachylenie $60^{\circ}$, a w jego pionowym profilu są dwie warstwy aluwiów. Najniższą warstwę, o miąższości $0,5 \mathrm{~m}$, tworzą średnie i grube żwiry. Ich nadkładem jest 2-metrowa pokrywa piasków i mułów, $\mathrm{z}$ cienkimi przewarstwieniami drobnych i średnich żwirów. Wskutek silnego nawilgocenia cała pokrywa jest spoista. Na powierzchni stoku terasy nie ma szczelin i spękań, tylko miejscami występują kanaliki biogenicznego pochodzenia. Na wysokości $1,5 \mathrm{~m}$ od podstawy brzegu umiejscowiono 6 prętów pomiarowych.

2. Sękowa (nr 2 na ryc. 1A) - stanowisko pomiarowe na lewym brzegu rzeki Sękówki, na podciętej terasie o wysokości $2,5 \mathrm{~m}$. W budowie osadów brzegu zaznaczają się dwie warstwy. Niższa warstwa, o miąższości 1 $\mathrm{m}$, jest złożona z mocno scementowanych żwirów. Na nich zalegają słabo spojone aluwia mułowo-piaszczyste i gliniaste. Podobnie jak na stanowisku Korczyna, brakuje w nich spękań, są jedynie kanaliki biogenicznego pochodzenia. Nachylenie powierzchni badanego brzegu wynosi $60^{\circ}$. Cztery pręty pomiarowe umiejscowiono na wysokości $1,7 \mathrm{~m}$ ponad podstawą brzegu.

\section{Brzegi zbudowane ze średnich i grubych żwirów}

1. Bielanka 1, Bielanka 2 (nr 3 i 4 na ryc. 1A) - stanowiska pomiarowe na prawym brzegu potoku Bielanka, na podcięciu erozyjnym terasy o wysokości 1,5 $\mathrm{m}$. Stok badanego brzegu jest $\mathrm{w}$ tym miejscu prawie pionowy i na całej wysokości odsłania się jego budowa wewnętrzna. Tworzą go dwie warstwy aluwiów. Niższa z warstw (1,3 miąższości) jest zbudowana ze średnich i grubych otoczaków, nie wysortowanych i słabo scementowanych piaskiem. Warstwę wyższą $(15-20 \mathrm{~cm})$ tworzą gliny $\mathrm{z}$ drobnoziarnistym piaskiem, o cementacji zbliżonej do niżej zalegających żwirów. Gliny w stropowej części są związane darnią. W obrębie warstwy górnej (na pograniczu ze żwirami) założono dwa stanowiska pomiarowe. Na pierwszym z nich zainstalowano 3 pręty erozyjne, na drugim -6 .

2. Chochołów (nr 1 na ryc. $1 \mathrm{~B}$ ) - stanowisko pomiarowe na lewym brzegu Czarnego Dunajca, na podciętej przez rzekę terasie skalno-osadowej o wysokość $6 \mathrm{~m}$. $\mathrm{W}$ profilu stoku tej terasy występują cztery warstwy osadów. Część dolną profilu (2 m wysokości) tworzy cokół z iłów neogeńskich. Na nim zalegają grube żwiry skał krystalicznych, bardzo słabo scementowane piaskiem z gliną ( $2 \mathrm{~m}$ miąższości). Wyższą część brzegu tworzy warstwa średnich żwirów silnie scementowanych $(1 \mathrm{~m})$, na której zalega warstwa mułowo-ilasta $\mathrm{z}$ torfem $(1 \mathrm{~m})$. Pręty pomiarowe zainstalowano w obrębie średnich żwirów, w miejscach umożliwiających ich montaż. 
3. Gladyszów (nr 5 na ryc. 1A) - stanowisko pomiarowe na prawym brzegu potoku Gdynianka. Brzeg w tym miejscu osiąga wysokość $7 \mathrm{~m}$, a jego profil poprzeczny jest dwuwarstwowy. Część dolną (4,5 $\mathrm{m}$ ), o nachyleniu $70^{\circ}$, tworzą średnie i grube żwiry mocno scementowane piaskiem i gliną. W części górnej, prawie pionowej, zalegają osady piaszczysto-mułowe, które w swej stropowej części są gliniaste. $\mathrm{W}$ warstwie tej pojawiają się miejscami soczewki drobnych i średnich żwirów. Obie części są oddzielone od siebie płaskim stopniem o szerokości $1 \mathrm{~m}$. Na wysokości $6 \mathrm{~m}$ od podstawy brzegu zamontowano 6 prętów pomiarowych.

\section{Brzegi zbudowane z litych skal}

1. Rozdziele (nr 6 na ryc. $1 \mathrm{~A}$ ) - miejsce pomiarów na lewym brzegu potoku Rozdzielanka. Odsłaniają się tam wychodnie łupkowo-piaskowcowego fliszu jednostki magurskiej. Odsłonięcie to ma do $3 \mathrm{~m}$ wysokości. Ławice piaskowców są tam cienkie i rzadko spękane. Łupki są gęściej spękane i jest ich 70-80\% w profilu odsłonięcia. Nadkładem warstw fliszu jest miąższa na 0,5 m pokrywa gliniasta, o małym stopniu cementacji, lecz silnie związana korzeniami roślin. U podstawy odsłonięcia zalega (do wysokości 0,8 m) łupkowy gruz osypiskowy. Na wysokości 1,5 m od podstawy brzegu zamontowano 3 pręty pomiarowe.

2. Ciche (nr 2 na ryc. $1 \mathrm{~B})$ - stanowisko pomiarowe na prawym brzegu potoku Cichy, w miejscu wysokiego (do $6 \mathrm{~m}$ ) podcięcia zbocza doliny przez rzekę. $\mathrm{Na}$ tym brzegu odsłaniają się ławice łupków i piaskowców fliszu podhalańskiego - warstwy chochołowskie dolne. Ich ułożenie jest monoklinalne, o upadzie $30^{\circ}$ w kierunku południowym (skośnie do biegu potoku). Warstwy łupków są porozdzielane cienkimi $(3-5 \mathrm{~cm})$ i grubymi $(30 \mathrm{~cm})$ ławicami piaskowców. Piaskowce średnioziarniste o spoiwie żelazisto-ilastym są gęsto spękane, gęstość spękań zwiększa się wraz z malejącą miąższością warstw. Sieć spękań w łupkach jest jeszcze gęstsza niż w piaskowcach. W badanym fragmencie brzegu zamontowano 2 pręty pomiarowe na wysokości $3 \mathrm{~m}$ od jego podstawy.

\section{Wyniki badań}

\section{Brzegi zbudowane z piasku i gliny}

Zachowanie się powierzchni stoku terasy na stanowisku Korczyna było różne w kolejnych okresach multigelacji

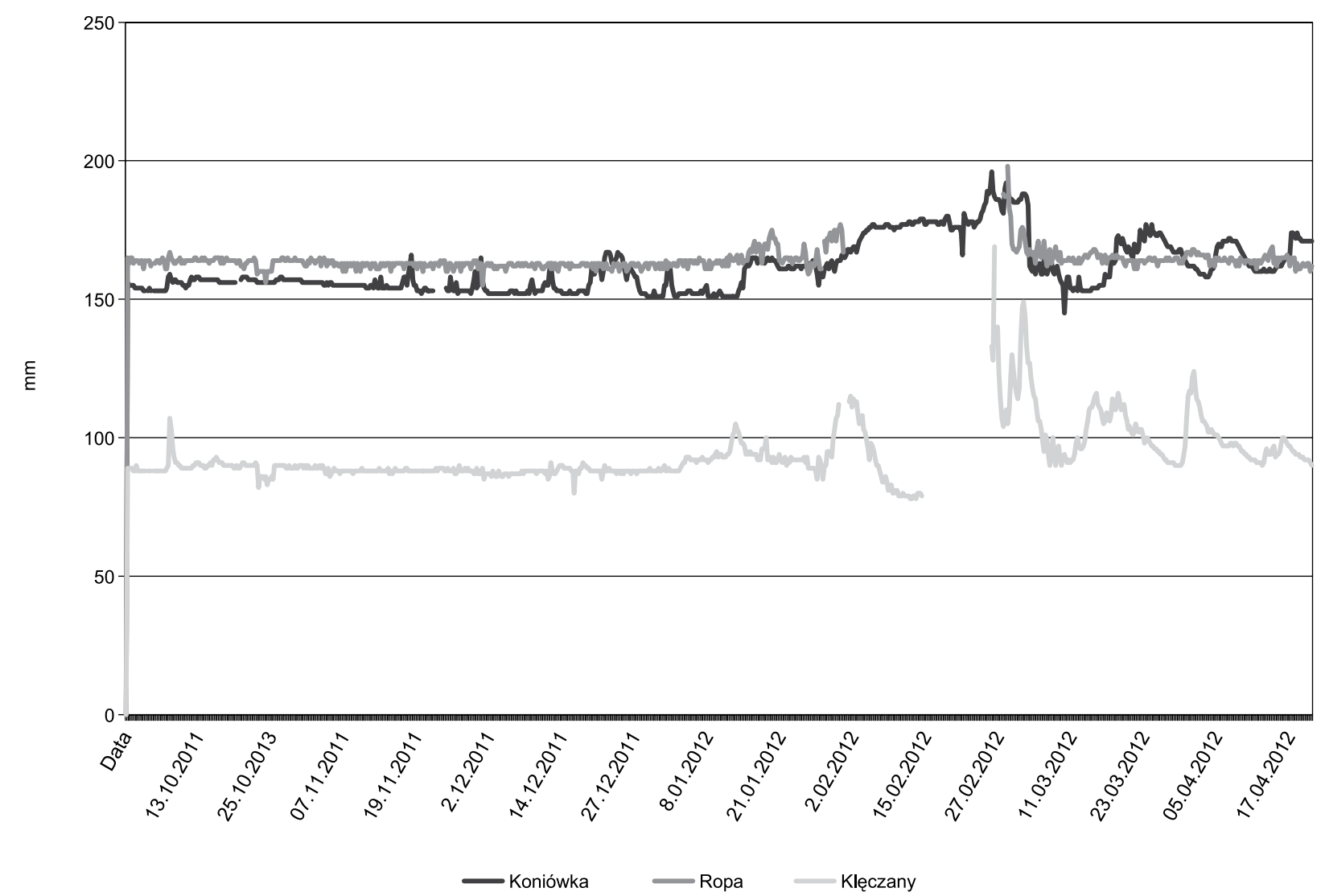

Ryc. 3. Wodostany Czarnego Dunajca na stacji Koniówka i Ropy na stacjach Ropa i Klęczany za okres 22.09.2011-21.04.2012 (dla Koniówki: NNW - 148; SSW - 173; WWW - 320; dla Klęczan: NNW - 50; SSW - 101; WWW - 665)

Źródło: opracowanie własne na podstawie danych IMGW.

Fig. 3. Czarny Dunajec water levels at the Koniówka station and Ropa water levels at the Ropa and Klęczany stations for the period 22.09.2011-21.04.2012 
(tab. 1). Średnia wielkość erozji tej powierzchni w otoczeniu prętów (średnia ze wszystkich prętów pomiarowych) w pierwszym i drugim okresie obserwacji wyniosła odpowiednio $0,7 \mathrm{~mm}$ i $1,7 \mathrm{~mm}$ (ryc. 4 ). Dopiero podczas trzeciego okresu cyklicznych wahań temperatury wokół $0^{\circ} \mathrm{C}$ nastąpił znaczny ubytek brzegu. Powierzchnia brzegu cofnęła się średnio o 40,3 mm, a kubatura materiału osypiskowego wzrosła 3-krotnie w stosunku do okresu wcześniejszego. W osypisku nagromadził się wyłącznie materiał najdrobniejszy (piaszczysto-gliniasty). Aktywność procesów mrozowych w kolejnym okresie multigelacji doprowadziła do cofnięcia się stoku terasy o dalsze 129 $\mathrm{mm}$. Kubatura materiału osypiskowego, zdeponowanego w stożkach u podstawy brzegu, wyniosła $0,04 \mathrm{~m}^{3}$ na każdy $1 \mathrm{~m}^{2}$ powierzchni brzegu.

Brzeg na stanowisku Sękowa nie wykazał aż tak wyraźnego cofnięcia powierzchni. W trakcie wszystkich okresów multigelacji praktycznie nie odnotowano jego erozji (tab. 1). Kubatura materiału osypiskowego była bardzo mała (do $0,003 \mathrm{~m}^{3} \mathrm{~m}^{-2}$ powierzchni brzegu po całym sezonie badawczym).

\section{Brzegi zbudowane ze średnich i grubych żwirów}

Na obszarze Beskidu Niskiego i Kotliny Orawsko-Nowotarskiej brzegi o takiej litologii osadów miały w kolejnych okresach multigelacji nierówną dynamikę przekształceń (tab. 1, ryc. 4). W trakcie dwóch pierwszych okresów multigelacji notowano na stokach badanych teras pęcznienie gruntu (Bielanka 1, Gładyszów) bądź erozję. Jednak rozmiary tych zmian były niewielkie mniejsze od $1 \mathrm{~cm}$. W tych samych okresach pomiarowych brzeg nad Czarnym Dunajcem (Kotlina Orawska) cofnął się prawie dwa razy dalej. W trakcie trzeciego okresu obserwacji na stanowisku Gładyszów zarejestrowano erozję brzegu o 1,2 cm, na stanowisku Bielanka $1-$ o 3,7 cm, a na stanowiskach Bielanka 2 i Chochołów - o około 6,5 $\mathrm{cm}$. Największe zmiany zarejestrowano dopiero w trakcie

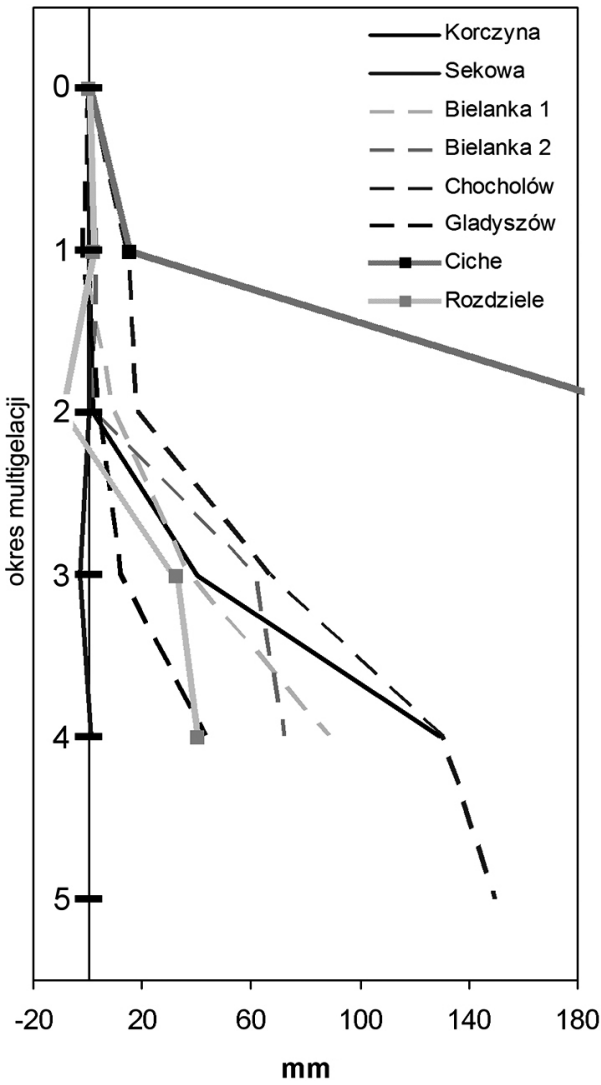

Ryc. 4. Średni rozkład położenia prętów w kolejnych okresach multigelacji na stanowiskach badawczych

Fig. 4. Average distribution of erosion pins in subsequent periods of multigelation on study sites

czwartego okresu obserwacji. Badany fragment brzegu w Chochołowie cofnął się o $13 \mathrm{~cm}$, a brzegi w Beskidzie Niskim o 4,3 cm (Gładyszów) lub 8,9 cm (Bielanka 1). Pod względem kubatury materiału osypiskowego rozrastające się stożki u podstawy brzegów potoku Bielanka i Czarnego Dunajca były wielkościowo podobne. Po całym okresie badań osiągnęły one przeciętną $0,2 \mathrm{~m}^{3} \mathrm{~m}^{-2}$

Tabela 1. Zmiany w odsłonięciu prętów pomiarowych i przyroście kubatury materiału osypiskowego

Table 1. Changes in the exposing of the erosion pins and the increase of volume of waste material

\begin{tabular}{|c|c|c|c|c|c|c|c|c|c|c|}
\hline \multirow{3}{*}{ Stanowisko } & \multicolumn{10}{|c|}{ Okres multigelacji } \\
\hline & \multicolumn{5}{|c|}{ Erozja brzegu $[\mathrm{mm}]$} & \multicolumn{5}{|c|}{$\begin{array}{l}\text { Kubatura materiału osypiskowego } \\
{\left[\mathrm{m}^{3} 1 \mathrm{~m}^{-2} \text { powierzchni brzegu] }\right.}\end{array}$} \\
\hline & 1 & 2 & 3 & 4 & 5 & 1 & 2 & 3 & 4 & 5 \\
\hline \multicolumn{11}{|c|}{ Brzegi zbudowane z drobnych aluwiów } \\
\hline Korczyna & 0,7 & 1,7 & 40,3 & 129,5 & & 0 & 0,007 & 0,02 & 0,04 & \\
\hline Sękowa & 0 & 0,5 & $-2,5$ & 1 & & 0 & 0,001 & 0,002 & 0,003 & \\
\hline \multicolumn{11}{|c|}{ Brzegi zbudowane ze średnich i grubych aluwiów } \\
\hline Bielanka 1 & $-2,3$ & 9,3 & 37,3 & 88,7 & & 0 & 0,007 & 0,07 & 0,2 & \\
\hline Bielanka 2 & 2,3 & 1,7 & 61,5 & 72,2 & & 0 & 0,01 & 0,08 & 0,16 & \\
\hline Chochołów & 14,2 & 18,2 & 66,7 & 130,3 & 149,8 & 0,003 & 0,005 & 0,17 & 0,2 & 0,2 \\
\hline Gładyszów & $-2,2$ & 4 & 12,2 & 43 & & 0,003 & 0,006 & 0,03 & 0,06 & \\
\hline \multicolumn{11}{|c|}{ Brzegi zbudowane $\mathrm{z}$ litych skał } \\
\hline Ciche & 15 & 203,5 & 231,5 & 306 & 310 & 0,01 & 0,02 & 0,07 & 0,08 & 0,08 \\
\hline Rozdziele & 2 & $-9,7$ & 32,7 & 40,3 & & 0,002 & 0,002 & 0,014 & 0,029 & \\
\hline
\end{tabular}

Wartości dodatnie oznaczają odsłonięcie prętów pomiarowych.

Wartości ujemne oznaczają zasłonięcie prętów pomiarowych. 
powierzchni brzegu. U podstawy potoku Zdynianka objętość materiału odspojonego była znacznie mniejsza i wyniosła $0,06 \mathrm{~m}^{3} \mathrm{~m}^{-2}$ powierzchni brzegu.

\section{Brzegi zbudowane z litych skal}

Różnice w cofaniu się brzegów rzek w Beskidzie Niskim i na Podhalu były największe dla brzegów zbudowanych z utworów fliszowych (tab. 1, ryc. 4). Podczas gdy stok terasy nad potokiem Rozdzielanka po 4 okresach multigelacji cofnął się o $4 \mathrm{~cm}$, nad potokiem Cichy cofnął się aż o $30,6 \mathrm{~cm}$. Istotne różnice notowano już od drugiego okresu multigelacji, gdy brzeg w Rozdzielu spęczniał o około $1 \mathrm{~cm}$, a nad Cichym cofnął się o ponad $20 \mathrm{~cm}$. Pod względem przyrostu kubatury materiału osypiskowego na stanowisku Rozdziele wielkość ta systematycznie rosła we w miarę równym tempie. Na stanowisku Ciche zmiany te miały przebieg bardziej skokowy. Znaczny przyrost materiału osypiskowego odnotowano tam głównie w trzecim okresie multigelacji i jego objętość nie zmieniła się znacząco w kolejnych okresach obserwacji.

\section{Wnioski}

Erozyjne skutki procesów mrozowych różniły się rozmiarami na każdym $\mathrm{z}$ trzech typów brzegów (różnych pod względem budowy i składu aluwiów). Najwolniej postępowała erozja brzegów zbudowanych z aluwiów homogenicznych, drobnoziarnistych (tab. 2, ryc. 5). Średnia wielkość tej erozji po całym okresie obserwacji wyniosła tam $6,5 \mathrm{~cm}$, a kubatura materiału osypiskowego $\mathrm{z} 1 \mathrm{~m}^{2}$ powierzchni brzegu $-0,0215 \mathrm{~m}^{3}$. Brzegi zbudowane $\mathrm{z}$ gliniastych piasków i mułków były niszczone w podobnym tempie na całej wysokości ich profilu (ryc. 6A). Jedynie górna, przykrawędziowa część brzegu, silniej związana przez korzenie roślin, ulegała erozji dużo wolniej.

$\mathrm{Na}$ brzegach zbudowanych ze średnich żwirów średnia wielkość cofnięcia się brzegu wyniosła $15 \mathrm{~cm}$. Kubatura materiału osypiskowego była największa ze wszystkich grup i osiągnęła wartość $0,23 \mathrm{~m}^{3} \mathrm{~m}^{-2}$ powierzchni stoku badanych brzegów (tab. 2, ryc. 5). Erozja przebiegała na nich dwukierunkowo i selektywnie. W pierwszej kolejności ulegał wyerodowaniu ze stoku materiał najdrobniejszy, upakowany pomiędzy otoczakami, który był deponowany u podstawy brzegu w rozrastających się stożkach osypiskowych. Następnie otoczaki po utracie

Tabela 2. Zmiany w odsłonięciu prętów pomiarowych i przyroście kubatury materiału osypiskowego (w ujęciu kumulatywnym)

Table 2. Changes in the exposing of the erosion pins and the increase of volume of waste material (cumulatively)

\begin{tabular}{|c|c|c|c|c|c|c|c|c|c|c|}
\hline \multirow{3}{*}{ Rodzaj brzegu } & \multicolumn{10}{|c|}{ Okres multigelacji } \\
\hline & \multicolumn{5}{|c|}{ Erozja brzegu $[\mathrm{mm}]$} & \multicolumn{5}{|c|}{$\begin{array}{c}\text { Kubatura materiału osypiskowego } \\
{\left[\mathrm{m}^{3} 1 \mathrm{~m}^{-2} \text { powierzchni brzegu] }\right.}\end{array}$} \\
\hline & 1 & 2 & 3 & 4 & 5 & 1 & 2 & 3 & 4 & 5 \\
\hline Brzegi zbudowane z drobnych aluwiów & 0,35 & 1,1 & 18,9 & 65,25 & & 0 & 0,004 & 0,011 & 0,022 & \\
\hline Brzegi zbudowane ze średnich i grubych aluwiów & 3 & 8,3 & 44,425 & 83,55 & 149,8 & 0,002 & 0,008 & 0,085 & 0,16 & 0,23 \\
\hline Brzegi zbudowane z litych skał & 8,5 & 96,9 & 132,1 & 173,15 & 310 & 0,006 & 0,011 & 0,042 & 0,055 & 0,08 \\
\hline
\end{tabular}
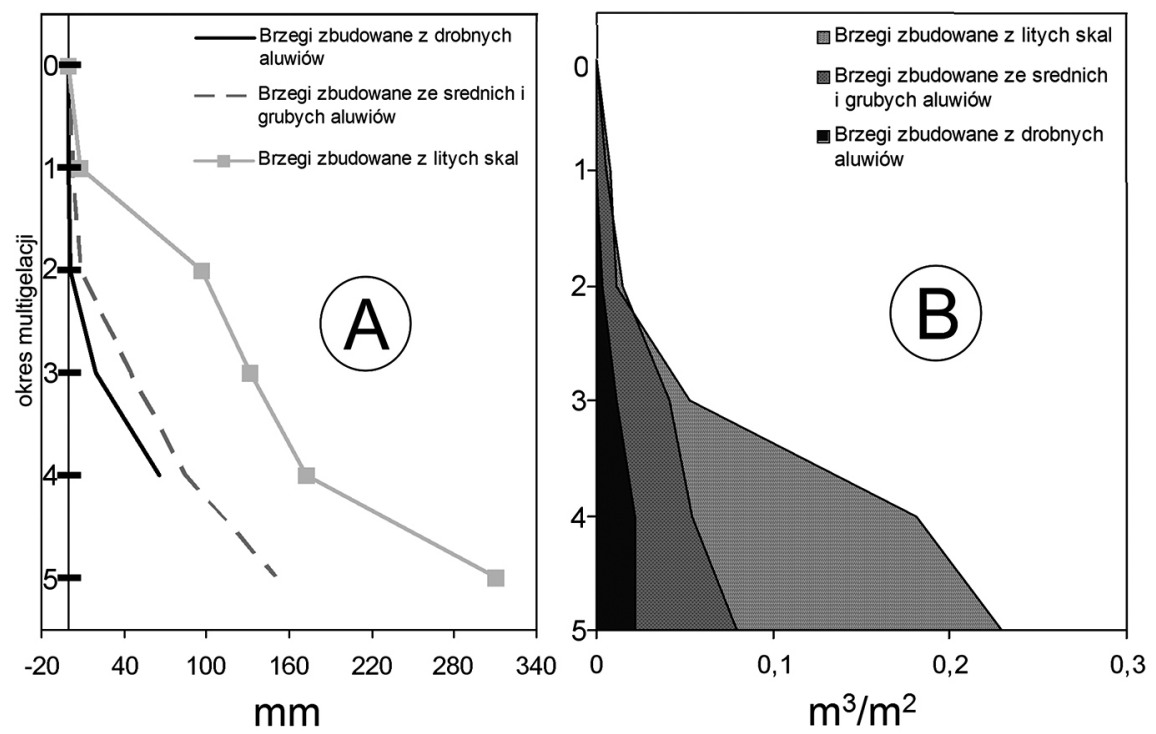

Ryc. 5. Rozkład położenia prętów w kolejnych okresach multigelacji (A) oraz przyrost kubatury zwietrzeliny mrozowej (B) na brzegach o różnej budowie geologicznej

Fig. 5. Location of pins in subsequent periods of multigelation (A) and an increase in volume of frost waste material (B) on the banks of different geological structure 
drobnej masy wypełniającej odspajały się od powierzchni brzegu i, zsuwając się po stoku, naruszały stabilność niżej leżących okruchów, przyśpieszając ich włączenie się do koluwiów zsuwających się po powierzchni stoku (ryc. 6B). Z osadów przy górnej krawędzi brzegu, które były silniej związane przez korzenie roślin, tworzyły się nawisy darniowe, które dopiero w okresie letnim, po ich dociążeniu wodą opadową, uległy oderwaniu.

Skaliste brzegi, zbudowane $\mathrm{z}$ fliszu łupkowo-piaskowcowego, były erodowane najbardziej. Średnia wielkość erozji (mierzona $\mathrm{z}$ wszystkich prętów na danym stanowisku) wyniosła $31 \mathrm{~cm}$. Objętość materiału odspojonego była względnie mała i osiągnęła wartość $0,08 \mathrm{~m}^{3} \mathrm{~m}^{-2}$ (tab. 2, ryc. 5). Przebieg erozji, podobnie jak na brzegach ze średnich żwirów, był stopniowy. Warstwy łupków, silniej i gęściej spękane, odpadały w pierwszej kolejności. Gdy spękane piaskowce, zalegające nad łupkami, traciły podparcie, wówczas były grawitacyjnie wyłamywane i zsuwały się do podnóża brzegu (ryc. 6C).

Badania erozji brzegów wskutek procesów mrozowych wymagają jednak zagęszczenia stanowisk pomiarowych oraz korelacji danych z przebiegiem wahań temperatury i wilgotności gruntu w sezonie jesienno-zimowym. Istotne jest również określenie przestrzennej zmienności natężenia tych procesów w odniesieniu do parametrów morfologicznych brzegów, ich ekspozycji i stopnia zadarnienia ich powierzchni. Ten słabo dotychczas poznany składnik erozji brzegów polskich rzek jest niewątpliwie destrukcyjny, ale jego mechanizm działania, aktywność i skutki można odnosić także do ziemnych form antropogenicznych.

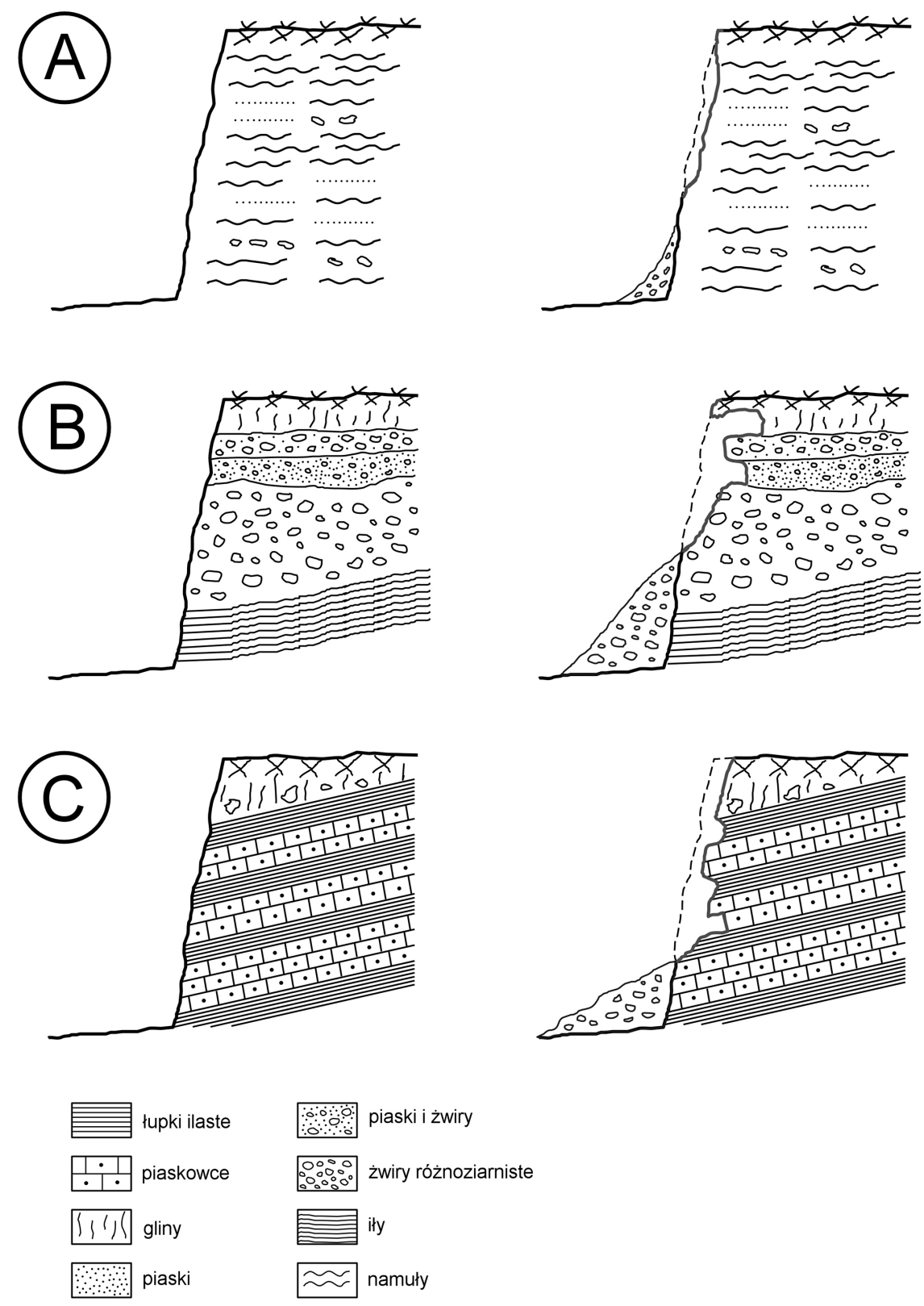

Ryc. 6. Schematyczny rozwój powierzchni brzegów o różnej budowie wewnętrznej

Fig. 6. A schematic development of the bank surface of varies internal structure 


\section{Literatura}

Allen P.M., Arnold J., Jakubowski E., 1999. Prediction of stream channel erosion potential. Environmental and Engineering Geoscience 3: 339-351.

Couper P., 2003. Effects of silt-clay content on the susceptibility of river banks to subaerial erosion. Geomorphology 56: 95-108, DOI:10.1016/S0169-555X(03)00048-5.

Couper P.R., Maddock I.P., 2001. Subaerial river bank erosion processes and their interaction with other bank erosion mechanisms on the River Arrow, Warwickshire, UK. Earth Surface Processes and Landforms 26(6): 631-646, DOI:10.1002/esp.212.

Dolnicki P., 2002. Wpływ pokrywy śnieżnej na termikę i grubość warstwy czynnej zmarzliny w obszarze tundrowym rejonu Polskiej Stacji Polarnej w Hornsundzie (SW Spitsbergen). Problemy Klimatologii Polarnej 12: 107-116.

Gatto L.W., 1995. Soil Freeze-Thaw Effects on Bank Erodibility and Stability. US Army Corps of Engineers. Cold Regions Research \& Engineering Laboratory. Special Report 95-24. Online 29.05.2013http://www.dtic.mil/cgi-bin/GetTRDoc?AD=ADA301818.

Grissinger E.H., 1982. Bank erosion of cohesive materials. W: R.D. Hey, J.C. Bathurst, C.R. Thorne (red.), Gravel-bed Rivers. John Wiley \& Sons, Chichester: 273-287.

Hubble T.C.T., Docker B.B., Rutherfurd I.D., 2010. The role of riparian trees in maintaining riverbank stability: A review of Australian experience and practice. Ecological Engineering 36(3): 292-304, DOI:10.1016/j.ecoleng.2009.04.006.

Hupp C.R., Schenk E.R., Richter J.M., Peet R.K., Townsend P.A., 2009. Bank erosion along the dam-regulated lower Roanoke River, North Carolina. The Geological Society of America, Special Paper 451: 97-108. Online: 29.05.2013 - http://profile.usgs.gov/myscience/ upload_folder/ci2012Feb1709513027921Hupp\%20et\%20al\%20 GSA,\%2009.pdf.

Knapen A., Poesen J., Grovers G., Gyssels G., Nachtergaele J., 2007. Resistance of soils to concentrated flow erosion: A review. Earth Science Reviews 80(1-2): 75-109, DOI:10.1016/j.earscirev.2006.08.001.

Kozielska-Sroka E., Michalski P., Zydroń T., 2010. Uwarunkowania geotechniczne i hydrodynamiczne transformacji północnej strefy brzegowej zbiornika Czorsztyn-Niedzica w trakcie jego eksploatacji. Monografie Pienińskie 2: 63-82.

Lawler D.M., 1993. Needle ice processes and sediment mobilization on river banks: the River Ilston, West Glamorgan, UK. Journal of Hydrology 150(1): 81-114, DOI:10.1016/0022-1694(93)90157-5.

Miller R.D., 1980. Freezing phenomena in soils. W: D. Hillel (red.), Applications of soil physics. Academic Press, New York: 245-299, DOI:10.1016/B978-0-12-348580-9.50016-X.
Mitchell S.B., Couperthwaite J.S., West J.R., Lawler D.M., 2003. Measuring sediment exchange rates on an intertidal bank at Blacktoft, Humber Estuary, UK. Science of the Total Environment 314-316: 535-549, DOI:10.1016/S0048-9697(03)00072-X

Przedwojski B., 1998. Morfologia rzek i prognozowanie procesów rzecznych. Wyd. Akademii Rolniczej im. Augusta Cieszkowskiego w Poznaniu.

Reid J.R., 1985. Bank-erosion processes in a cool-temperate environment, Orwell Lake, Minnesota. Geological Society of America Bulletin 96(6): 781-792, DOI: 10.1130/0016-7606(1985)96<781:BPIA$\mathrm{CE}>2.0 . \mathrm{CO} ; 2$.

Saynor M.J., Loughran R.J., Wayne D.E., Scott P.F., 1994. Sediment movement on hillslopes measured by caesium-137 and erosion pins. Variability in Stream Erosion and Sediment Transport. Proceedings of the Canberra Symposium, December 1994. IAHS Publ. 224: 87-93. Online: 29.05.2013 - http://iahs.info/redbooks/a224/iahs_224_0087. pdf.

Teisseyre A.K., 1984. Procesy fluwialne i rozwój koryta górnego Bobru na odcinku badawczym w Błażkowej (1967-1982). Geologica Sudetica 19(1): 7-71.

Thorne C.R., 1982. Processes and mechanisms of river bank erosion. W: R.D. Hey, J.C. Bathurst, C.R. Thorne (red.), Gravel-Bed Rivers. Wiley. Chichester: 227-272.

Thorne C.R., 1990. Effects of vegetation on river bank erosion and stability. W: J.B. Thornes (red.), Vegetation and Erosion. Wiley, Chichester: $125-144$.

Thorne C.R., Osman A.M., 1988. The influence of bank stability on regime geometry of natural channels. W: W.R. White (red.), International Conference on River Regime. Hydraulics Research. Wallingford: $134-148$.

Walker J., Arnborg L., Peippo J., 1987. Riverbank erosion in the Colville Delta, Alaska. Geografiska Annaler Series A, Physical Geography 69(1): 61-70.

Webb R.H., Wilshire H.G., Henry M.A., 1983. Natural recovery of soils and vegetation following human disturbance. W: R.H. Webb, H.G. Wilshire (red.), Environmental effects of off-road vehicle impacts and management in arid regions. Springer-Verlag, New York: 279-302.

Wolman M.G., 1959. Factors influencing erosion of a cohesive river bank. American Journal of Science 257: 204-216.

Wynn T.M., 2004. The Effects of Vegetation on Stream Bank Erosion. Virginia Polytechnic Institute and State University Doctor of Philosophy Dissertation, Blacksburg, VA.

Zwoliński Z., 1988. Metody badań erozji bocznej w korytach rzecznych: przegląd i zastosowane techniki na Parsęcie. Badania Fizjograficzne nad Polska Zachodnią 38: 179-212. 